\title{
FINANCE AND INEQUALITY IN EIGHT ASIAN COUNTRIES: DOES SIZE MATTER
}

\author{
Mansor Ibrahim ${ }^{1}$ \\ ${ }^{1}$ International Centre for Education in Islamic Finance, Kuala Lumpur, Malaysia. \\ E-mail: mansorhi@inceif.org
}

\begin{abstract}
The present paper seeks to assess the implications of increasing financial sector size on income inequality in eight Asian countries - Hong Kong, India, Indonesia, Japan, Malaysia, the Philippines, Singapore, and South Korea. Adopting a panel data approach, it document a non-linear relation between income inequality and financial sector size in these countries. More precisely, the increasing financial sector size is favourable to equal income distribution only up until a size threshold, beyond which further expansion of the financial sector can worsen income distribution. The analysis further highlights the income-equalizing effect of economic growth and infrastructure development and the income un-equalizing effect of trade and government expenditures. These results are robust to alternative model specifications and to exclusion of a country at a time from the sample.
\end{abstract}

Keywords: Income inequality; Financial sector size; Asian countries.

JEL Classification: C14; G21.

Article history:

Received : March 2, 2018

Revised : : May 4, 2018

Accepted : July 29, 2018

Available online : July 31, 2018

https://doi.org/10.21098/bemp.v21i1.930 


\section{INTRODUCTION}

In the literature, there are various contentious predictions of the finance inequality relations. The presence of financial market frictions and credit constraints is viewed to be an impediment to financial access by small enterprises and the poor and, hence, accounts for persistent inequality. Accordingly, financial deepening by enhancing financial access and alleviating credit constraints will help equalize income distribution (Banerjee and Newman, 1993; Galor and Zeira, 1993; Mookherjee and Ray, 2003). By contrast, the progress of the financial markets has the potential to widen income inequality if the poor remains segmented from the establishments of formal financial institutions and their developments are captured by established interest (Rajan and Zingales, 2003; Claessens and Perotti, 2007). Greenwood and Jovanovic (1990) further posit a non-linear relationship between finance and income inequality. Their theoretical model is based on the premise that there is a fixed cost to financial access. Accordingly, at the early stage of financial development, the poor will be left out leading to higher income inequality. However, at a later stage, financial development will have an incomeequalizing effect as income accumulates and the fixed cost becomes affordable by more people.

Existing empirical evidence, which is pre-dominantly based on the empirical link between measures of financial development and measures of income inequality for individual countries or for a panel of countries, remains elusive. Evaluating the Indian experience, Ang (2010) comes to the conclusion that financial development does reduce income inequality. Using panel samples of developed and developing countries, Clarke et al. (2006), Beck et al. (2007) and Hamori and Hashiguchi (2012) provide further empirical evidence that financial development is favourable to income distribution. By contrast, Rodriguez-Pose and Tselios (2009) and Gimet and Lagoarde-Segot (2011) document inequality-increasing effect of financial development. The recent work by Bahmani-Oskooee and Zhang (2015) well reflects the different relations between finance and income distribution across many countries. They examine time series data of 17 countries and find income-equalizing effect of financial development in the short run for 10 countries and un-equalizing effect for five countries. Further, only in three countries the positive relation between finance and income distribution prevails in the long-run.

In parallel to the finance - growth literature ${ }^{2}$, some recent studies on the issue empirically emphasize various conditions embedded in the aforementioned theoretical views in shaping finance - inequality relations. These include institutional quality, levels of financial and economic developments, financial access and even typologies of reforms. For instance, Kim and Lin (2011) specify

2 Empirical studies on finance - growth nexus has evolved from assessing direct empirical relations between finance and growth to recently emphasizing the importance of various conditions for the beneficial growth effects of finance to be realized. These conditions include institutional quality, level of development, inflationary environment, government size and financial access (Demetriades and Law, 2006; Huang and Lin, 2009; Yilmazkuday, 2011; Abdmoulah and Jelili, 2013; Law et al., 2013). Several recent studies have also argued and advanced evidence against "too much" finance. That is, finance is good for growth only up to a certain threshold size, after which it has adverse repercussion on growth (Checchetti and Kharroubi, 2012; Law and Singh, 2014). 
the relation between financial development and inequality to be contingent on the level of financial development. Utilizing cross-sectional samples of more than 50 countries and a threshold regression approach, they find evidence for inequality-reducing effect of financial development only when the level of financial development has reached a certain threshold. Hamori and Hashiguchi (2012) emphasize instead economic growth as a condition. Interestingly, while financial deepening is found to reduce inequality in an unbalanced panel of 126 countries, economic growth tends to suppress the equalizing effect of financial development. In a more recent study, Law et al. (2014) demonstrate the importance of institutional quality in supporting the favourable role of finance in income distribution. Employing a cross-national data of 81 countries and the institutional indicators by the International County Risk Guide (ICRG) and by Kaufmann et al. (2008), they indicate the need for a country to reach an institutional quality threshold, beyond which financial development will exert a positive effect on income distribution. Finally, Mokerjee and Kalipioni (2010) and Agnello et al. (2012) pinpoint respectively financial access and typologies of reforms to be central.

While these studies have offered some progresses in our understanding of the factors shaping the finance - inequality relations, they have not covered an essential spectrum of finance, namely, the financial market size. Arguably, the financial market size can be important to income inequality and their relations can potentially be non-linear. The size of the financial markets is amicable to equal income distribution to the extent that it widens financial access and relaxes credit constraints. However, the increase in the financial sector size is not necessarily monotonically related to finance access and relaxation of credit constraints. The increasing size of the financial sector may reflect its expansion to nonintermediation activities and disproportionately draw human talents to the sector. As emphasized by Cœurè (2014) in his address at the ECB conference, this can be highly inefficient when the financial sector is very large since it is likely that the social returns to financial services are lower than their private returns. Thus, through these mechanisms, inequality may heighten when the sector is oversized. While the recent empirical studies have warned against the growth-impeding effects of oversized financial sector (Checchetti and Kharroubi, 2012; Law and Singh, 2014; Beck et al., 2014), its bearings on inequality has surprisingly received virtually no empirical attention.

This paper attempts to contribute to this neglected aspect of finance-inequality relations by drawing from the experiences of eight Asian countries - Hong Kong, India, Indonesia, Japan, Malaysia, the Philippines, Singapore, and South Korea. These countries have witnessed rapid growth in their economic activities and, at the same time, are progressing rapidly in their financial fronts. Still, most of them continue to face rising income inequality. Among the eight Asian countries, rising trends in income inequality are apparent in Hong Kong, India, Japan, Korea and Singapore. In the Philippines, income inequality has also risen recently. A recent study by Perera and Lee (2013) for nine Asian countries find no evidence that economic growth is significantly related to income inequality ${ }^{3}$. Further, they find some evidence suggesting worsening income distribution as the quality of

3 The countries covered in Perera and Lee (2013) are Bangladesh, India, Pakistan, Sri Lanka, China, Indonesia, Malaysia, Philippines and Thailand. 
institutions improves. However, they have not considered financial factors and controlled for other variables that might be relevant. In this paper, we add to the literature by exploring whether rising income inequality is the consequence of expanding financial sector size. This would be important for carving appropriate financial sector policies not only for the eight Asian countries but also for other countries moving upward the development ladder through finance-oriented strategies.

Our focus on a panel of eight Asian countries can be viewed as a compromise between using time series data of individual countries and cross-sectional or panel data of many countries. As noted by Creel et al. (2015), a key constraint of time series studies is data availability. Normally, income inequality for a country is available for a short span and, at the same time, does not exhibit much variations. To increase the sample size as well as variations in inequality, many studies have adopted cross-sectional and panel data in their analyses. This data structure, however, has its own limitation. By lumping highly heterogeneous countries into one sample, any result only suggests averaged relation among the variables under study and accordingly masks potential heterogeneity among them (Ram, 1999; Creel et al., 2015; Bahmani-Oskooee and Zhang, 2015). Moreover, whether including individual-specific effects to account for heterogeneity would be satisfactory remains uncertain, especially when country differences are multidimensional, and hence our focus on these eight Asian countries with at least similar experiences of growth trajectory. Still, in the analysis, we take a caution by addressing heterogeneity issue even in this group of countries.

As a preview to our results, we find robust evidence supporting the U-shaped relations between financial sector size, measured by the share of financial sector value added, and income inequality. Thus, the financial market helps reduce income inequality only when it is not oversized. Once it passes a certain threshold size, it worsens income inequality in these countries. The rest of the paper is structured as follows. To place the present study in context, the next section describes the data used and highlight relevant stylized facts. Then, section III details the empirical approach. This is followed by result presentation and discussion in section IV. Finally, section $\mathrm{V}$ summarizes the main findings and provides concluding remarks.

\section{DATA AND STYLIZED FACTS}

We put together data from three different sources for the purpose of the present analysis. The list of countries includes Hong Kong, India, Indonesia, Japan, Malaysia, the Philippines, Singapore, and South Korea. The income inequality is the Estimated Household income inequality (EHII) measured in GINI format and developed by the University of Texas Inequality Project(UTIP, 2008), the advantages of which are elaborated in Herzer and Nunnenkamp (2012) and Asteriou et al. (2014). More specifically, apart from providing a sufficiently long time series, the UTIP inequality data are comparable across space and time (Galbraith and Kum, 2005). The finance sector size is measured by the share of finance sector value added provided by Groningen Growth and Development Centre (Timmer et al., $2014)^{4}$. Apart from these two key variables, we also include several controlled

4 The GGDC 10-Sector database of the Centre provides international comparable annual time series of value added, output deflators, and persons employed in various sectors. 
variables deemed relevant to income inequality. These are the growth rate of real GDP per capita, the CPI-based inflation rate, trade openness measured by the sum of exports and imports to GDP ratio, aggregate credit to the private sector to GDP ratio, bank credit to the private sector to GDP ratio, M2 money supply to GDP ratio, market capitalization to GDP ratio, government consumption to GDP ratio and infrastructure proxied by the number of phone lines per 100 people. These data are sourced from the World Development Indicators. The data are annual covering mostly the period $1988-2007^{5}$.

The countries covered are at different stages of development but represent fast growing economies of Asia, not only in terms of their real GDP but also in their financial sector size (Table 1). With the exception of Japan and the Philippines, these countries recorded average annual growth rates of real GDP per capita above $3 \%$ over the sample period. In addition, the growth of the financial sectors in these countries, except India and South Korea, is substantial as manifested by their sizes at the beginning and end of the sample period. Being the financial centres in the region, it is not surprising that Hong Kong and Singapore have the largest financial sector sizes and are still experiencing marked increase in the share of the financial sector over the years. Despite financial difficulties experienced by Japan, its financial sector is relatively large as compared to other countries in the region. The share of the financial sector value added also surpassed $10 \%$ in India, Malaysia, and the Philippines in recent years. Among the sample countries, only Indonesia and Korea have the financial sector value added to be less than $10 \%$ of the total value added.

Table 1.

Growth and Financial Sector Size of Sample Countries

\begin{tabular}{|c|c|c|c|c|c|c|c|c|}
\hline & HK & IN & IND & JP & $\mathrm{KR}$ & MY & PH & SG \\
\hline \multicolumn{9}{|c|}{ Real GDP per capita } \\
\hline Mean & 23011.65 & 546.8 & 1082.94 & 33340.9 & 13635.02 & 4448.87 & 1047.16 & 23313.9 \\
\hline Std Dev & 3561 & 142.87 & 176.37 & 2136.48 & 3502.39 & 934.46 & 84.17 & 5438.05 \\
\hline \multicolumn{9}{|c|}{ Real GDP per capita Growth } \\
\hline Mean & 3.15 & 4.64 & 3.58 & 1.73 & 5.35 & 4.3 & 1.57 & 4.24 \\
\hline Std Dev & 3.52 & 2.42 & 4.65 & 2.08 & 3.56 & 3.88 & 2.23 & 3.91 \\
\hline \multicolumn{9}{|c|}{ Financial Sector Size } \\
\hline Mean & 25.5 & 8.02 & 6.13 & 14.01 & 9.39 & 10.73 & 10.96 & 21.62 \\
\hline Std Dev & 2.64 & 1.61 & 0.93 & 1.35 & 0.77 & 1.59 & 1.33 & 1.99 \\
\hline Begin & 21.72 & 6.06 & 4.42 & 12.86 & 8.14 & 7.23 & 8.34 & 17.07 \\
\hline End & 30.73 & 10.67 & 5.08 & 16.13 & 9.19 & 12.54 & 13.13 & 25.76 \\
\hline
\end{tabular}

Note: $\mathrm{HK}=$ Hong Kong; IN = India; IND = Indonesia; JP = Japan; KR = South Korea; MY = Malaysia; $\mathrm{PH}$ = The Philippines; SG = Singapore

5 The sample spans for respective countries are: Hong Kong (1991 - 2008), India (1988 2007), Indonesia (1988 - 2007), Japan (1988 - 2007), Korea (1989 - 2006), Malaysia (1988 - 2007), the Philippines (1988 - 2006), and Singapore (1988 - 2008). 
As demonstrated in Figure 1, the increase in the financial sector is only loosely directly related to the size of credit to the private sector, an often-used measure of financial development or intermediation. Indeed, their positive relations are most apparent only in India and Indonesia, the countries that have the smallest initial financial sector size. In highly-developed financial market economies such as Hong Kong, Japan, Korea, and Singapore, the increase in the size of the financial sector is initially directly related to the ratio of credit to the private sector (as \% of GDP). However, further expansion in the financial sector size does not seem to be related or even negatively related to aggregate credit to GDP ratio. A similar pattern is also observed for Malaysia and the Philippines.

HONG KONG

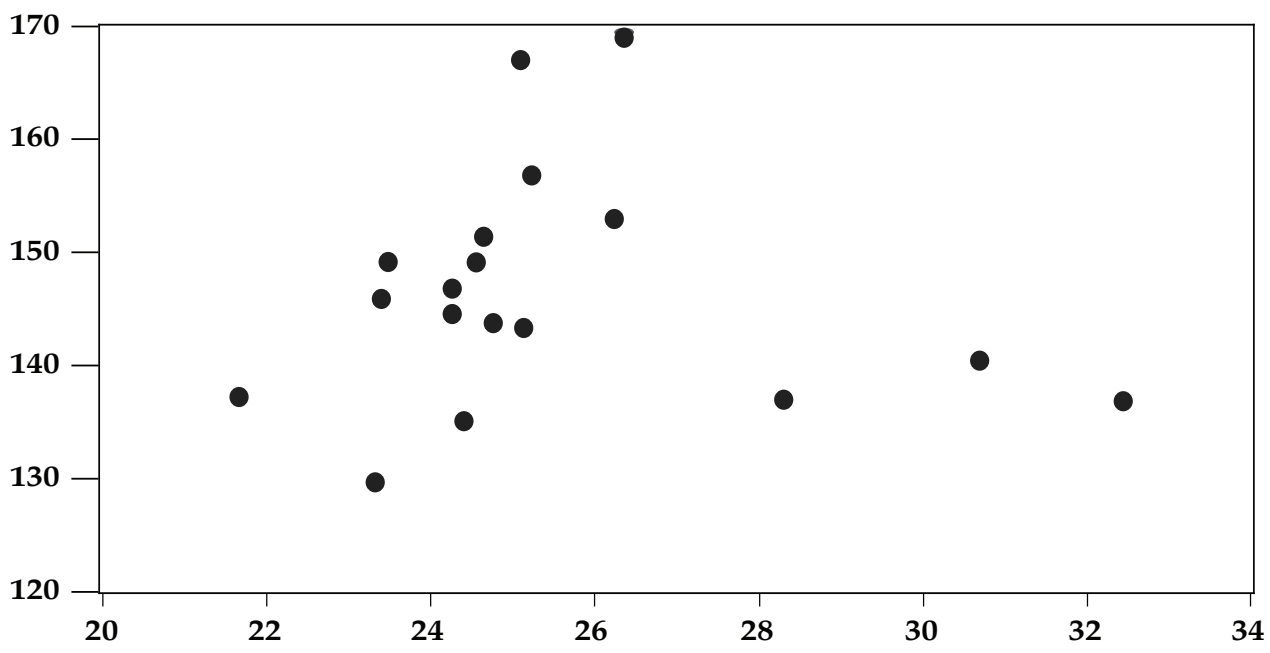

INDIA

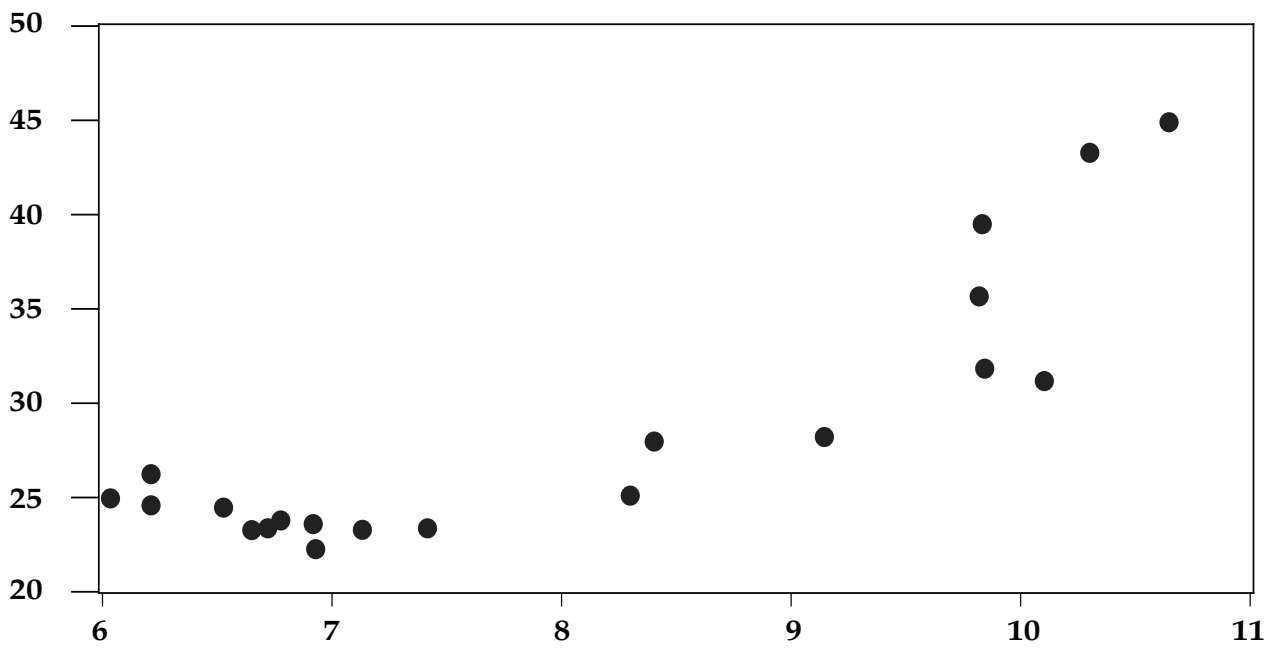

Figure 1. Financial Market Intermediation and Size 
INDONESIA
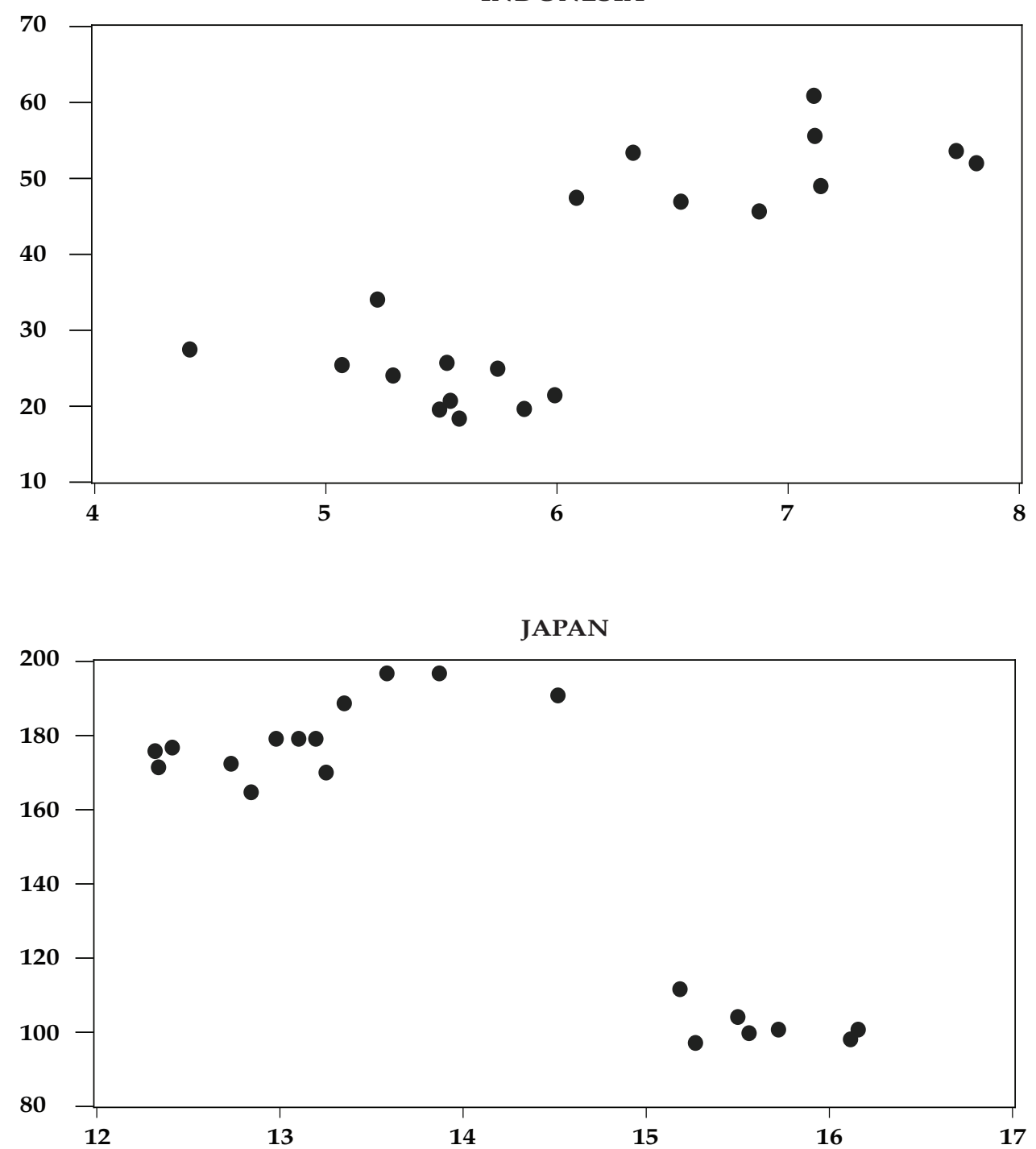

Figure 1. Financial Market Intermediation and Size (Continued) 

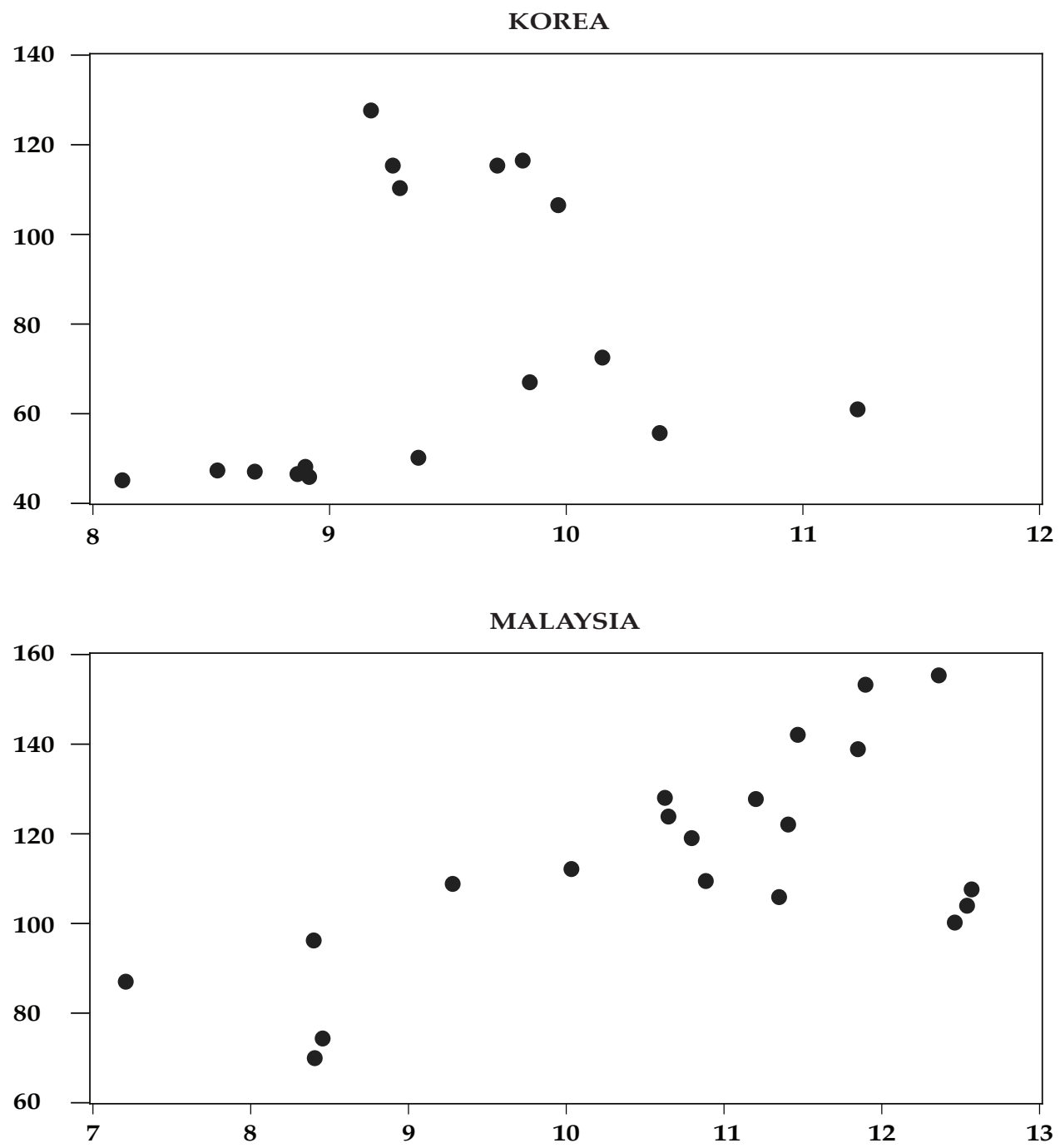

Figure 1. Financial Market Intermediation and Size (Continued) 
PHILIPPINES

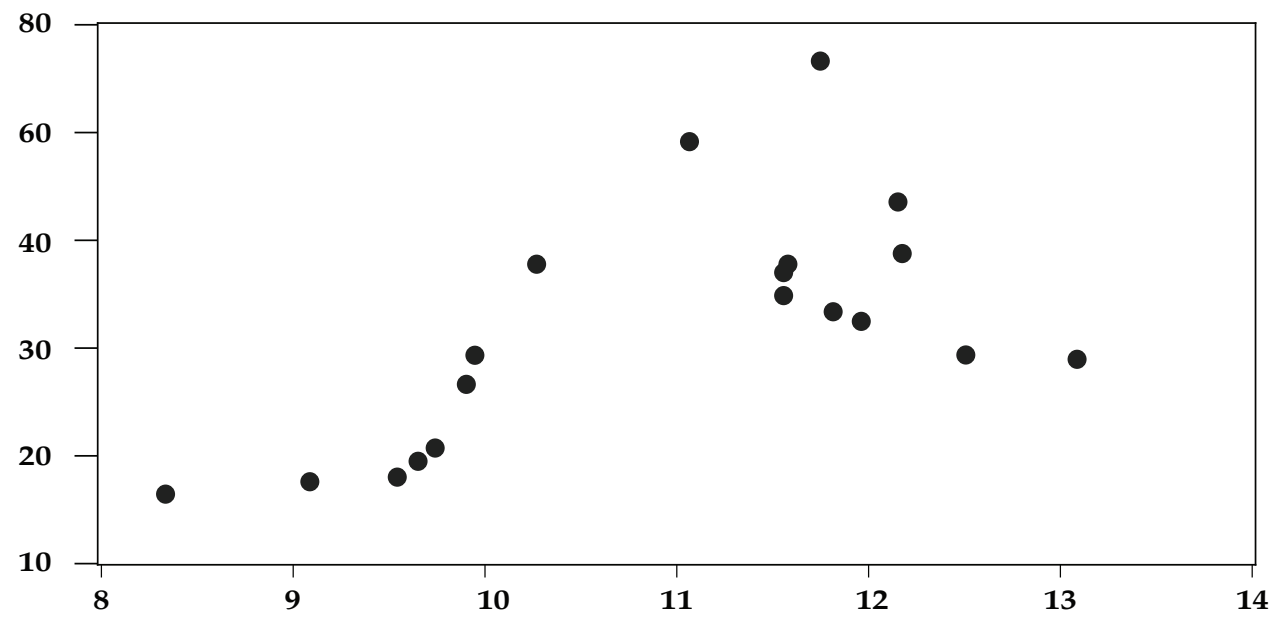

SINGAPORE

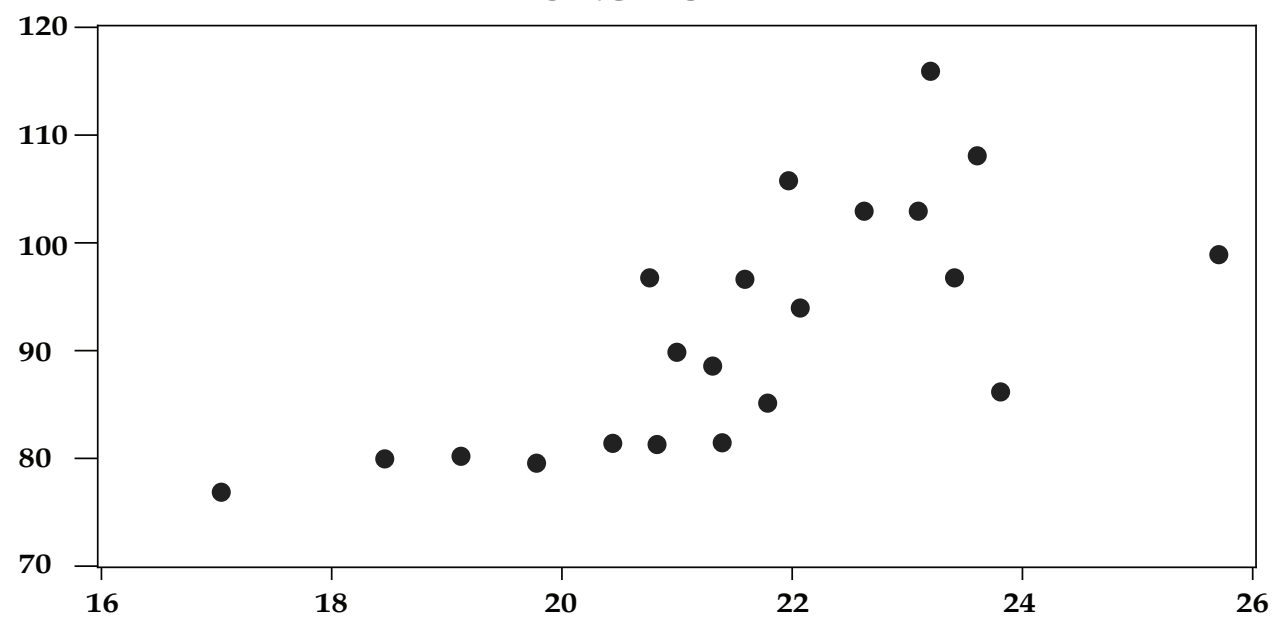

Note: the Y-axis is credit to the private sector (\% GDP) and the X-axis is the share of financial sector value added.

Figure 1. Financial Market Intermediation and Size (Continued) 
Figure 2 depicts the evolution of income inequality in these eight Asian countries. When viewed together with Table 1 and Figure 1, interesting observations emerge. In countries with high growth (i.e. more 3\% growth rates in real GDP per capita) and substantial increase in the financial sector size, i.e. Hong Kong and Singapore, the income inequality exhibits an uptrend pattern. It seems to be premature to argue that economic growth has widened income distribution in these countries. Given their levels of income per capita, reduction in income inequality should be more expected. If the postulation of the Kuznets curve is right, then these countries are more likely to surpass a threshold income level beyond which economic development should be beneficial for income distribution. However, it is also uncertain to attribute the increase in income inequality to expanding market size in this group of countries. On one hand, the experience of India that sees direct relation between financial market size and credit and hence potentially widened financial access would suggest the decline in income inequality. However, India has also witnessed rising income inequality, which may be due to its rapid growth or other factors. The Korean case further supports this contention since, despite marginal increase in financial market size, has also witnessed rising income inequality. On the other hand, the rising income inequality in the Philippines amidst its low growth could mean that its expanding market size is responsible. A similar argument can be made for Japan and Malaysia. In a nutshell, these observations highlight the need to examine formally the financial sector size - inequality relations.

HONG KONG

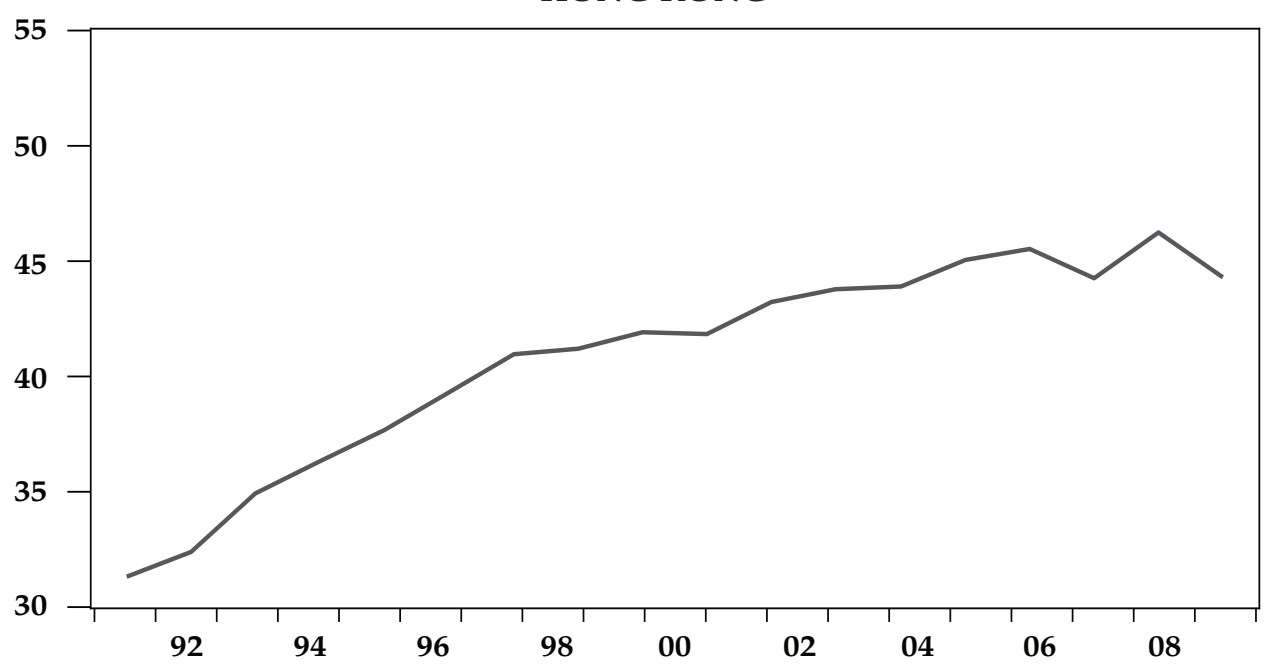

Figure 2. Income Inequality in Eight Asian Countries 
HONG KONG

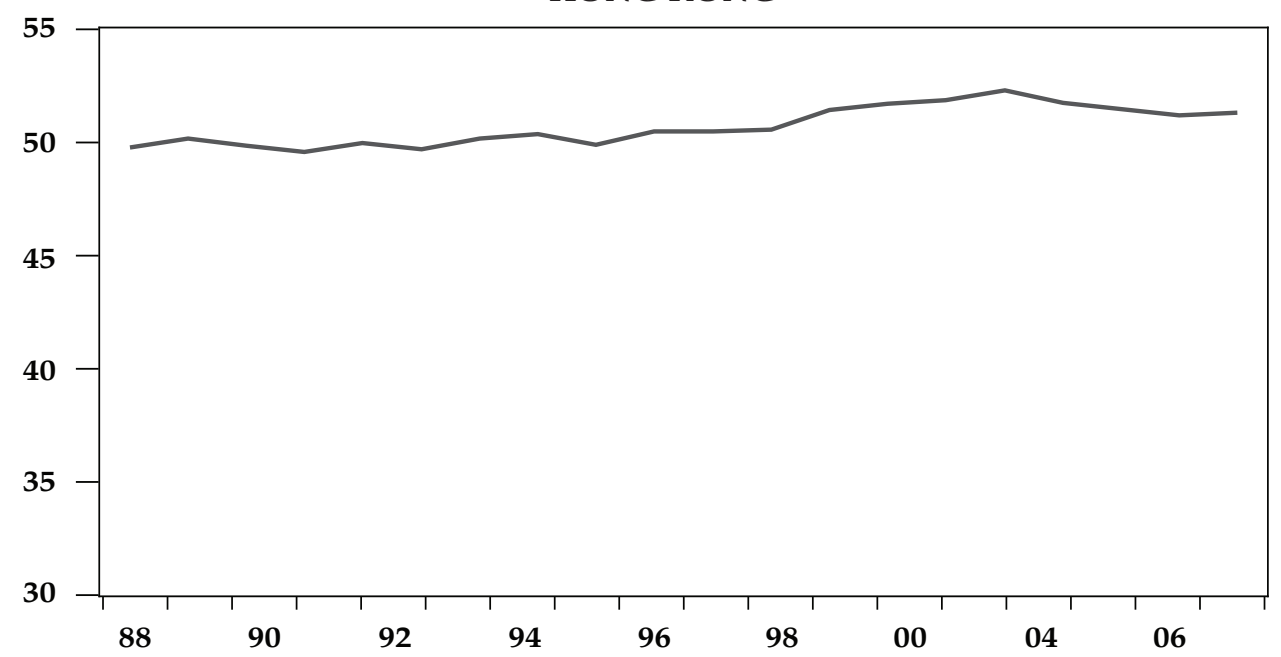

INDONESIA

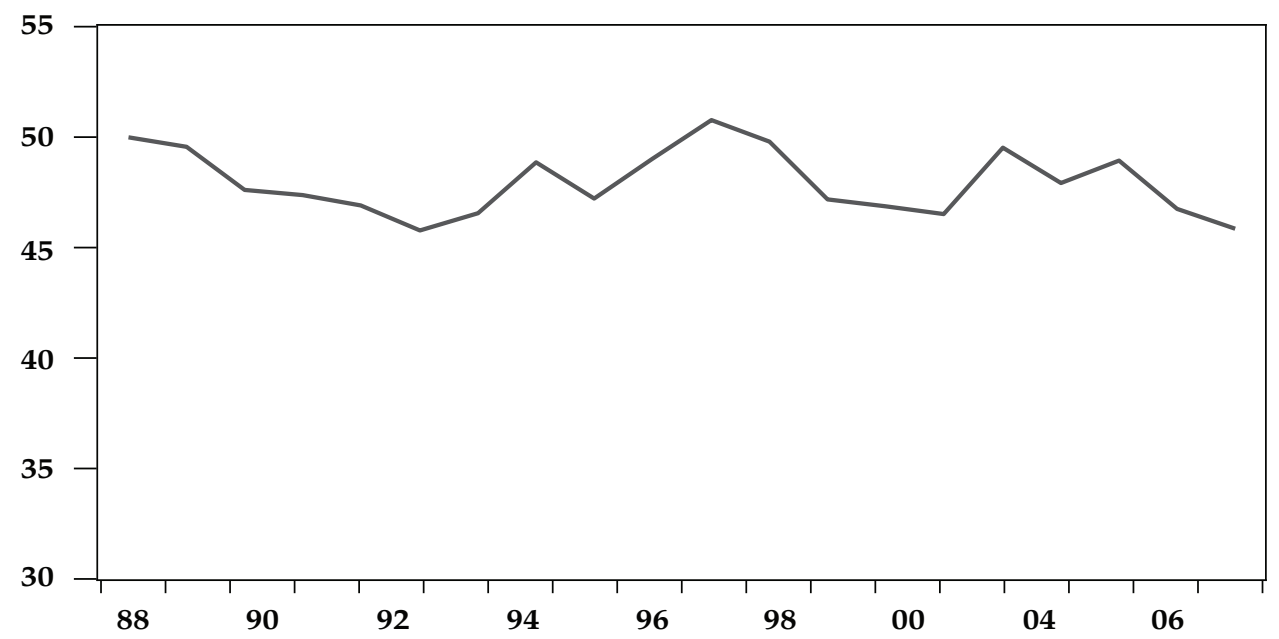

Figure 2. Income Inequality in Eight Asian Countries (Continued) 

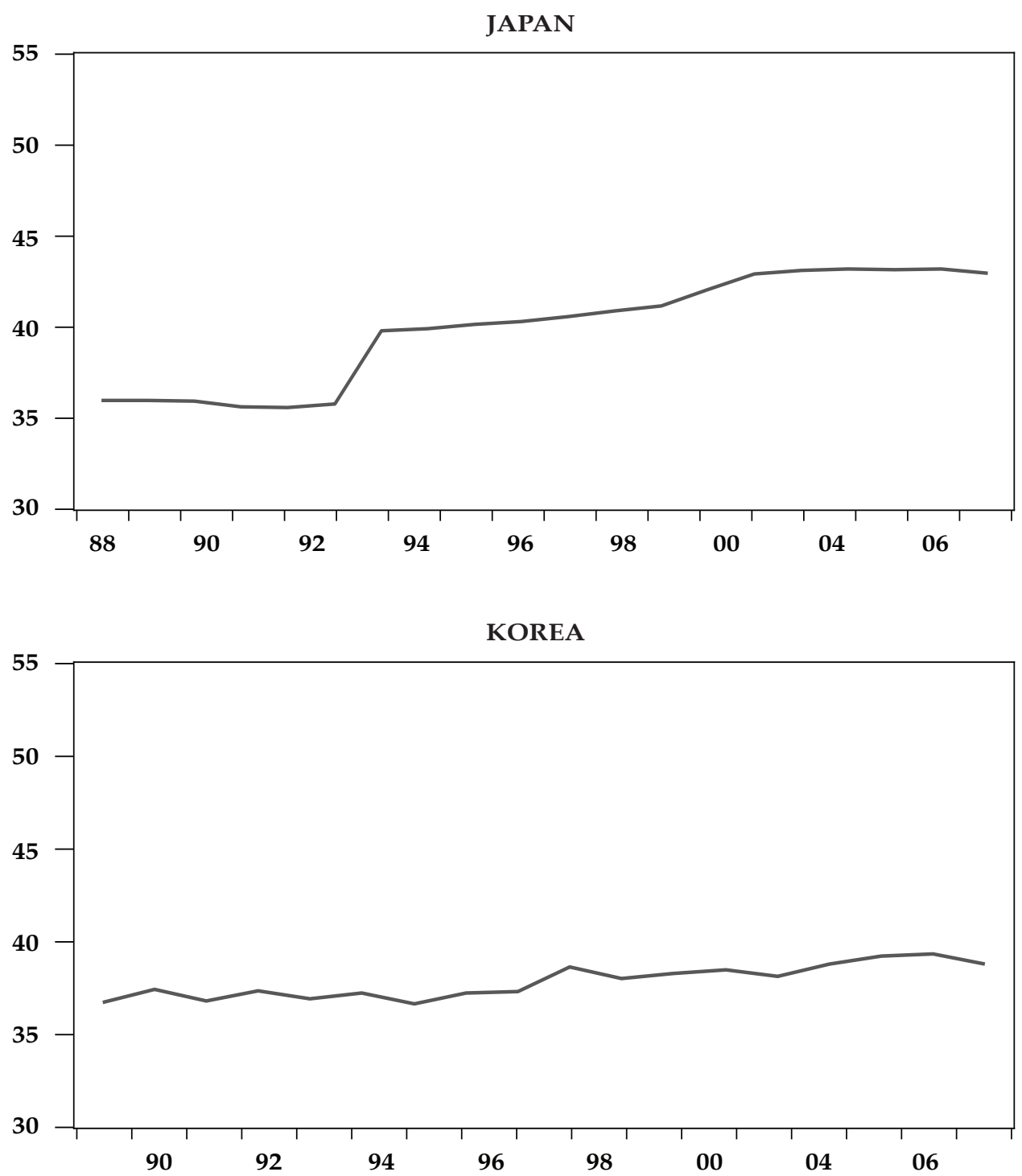

Figure 2. Income Inequality in Eight Asian Countries (Continued) 

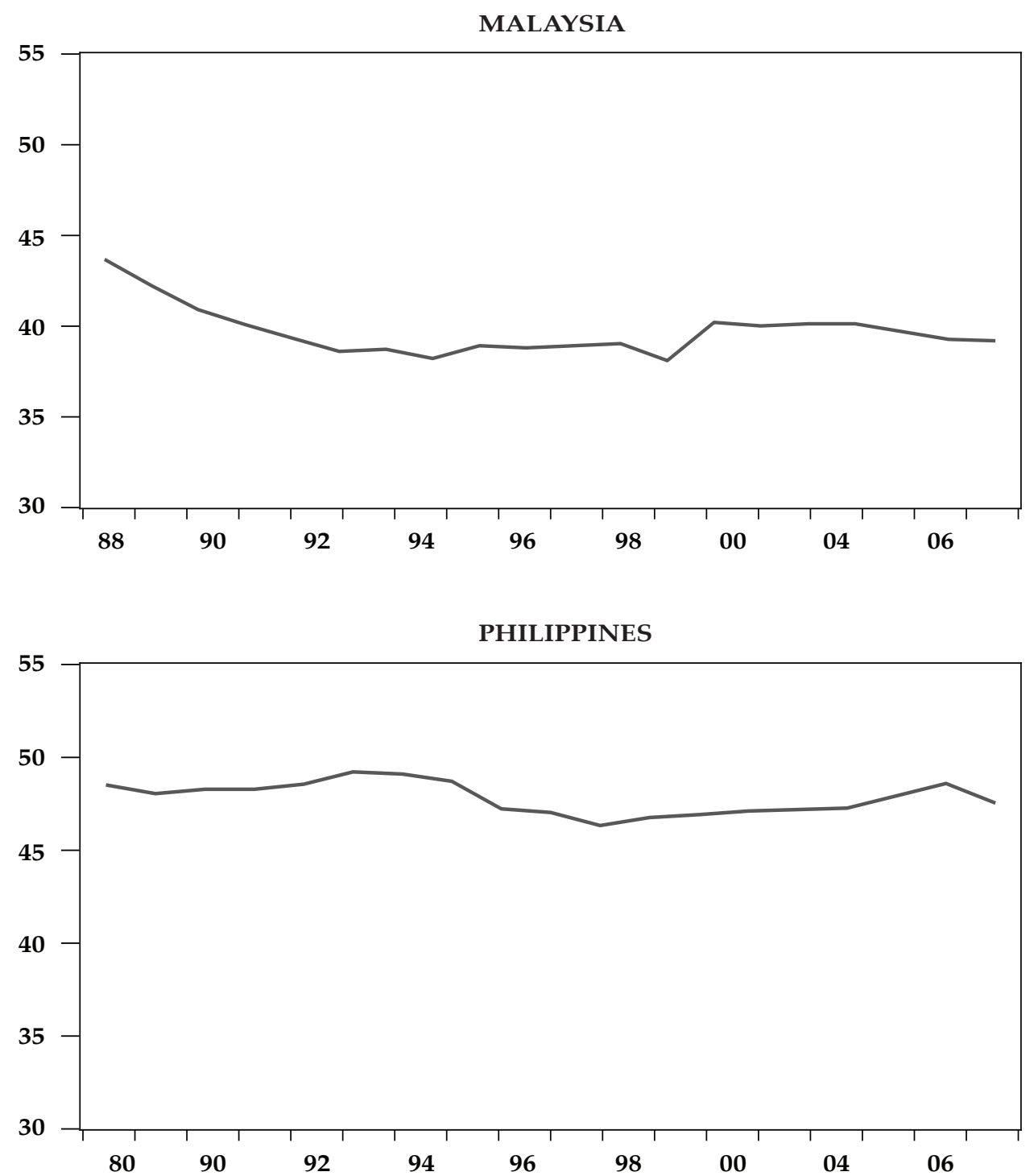

Figure 2. Income Inequality in Eight Asian Countries (Continued) 


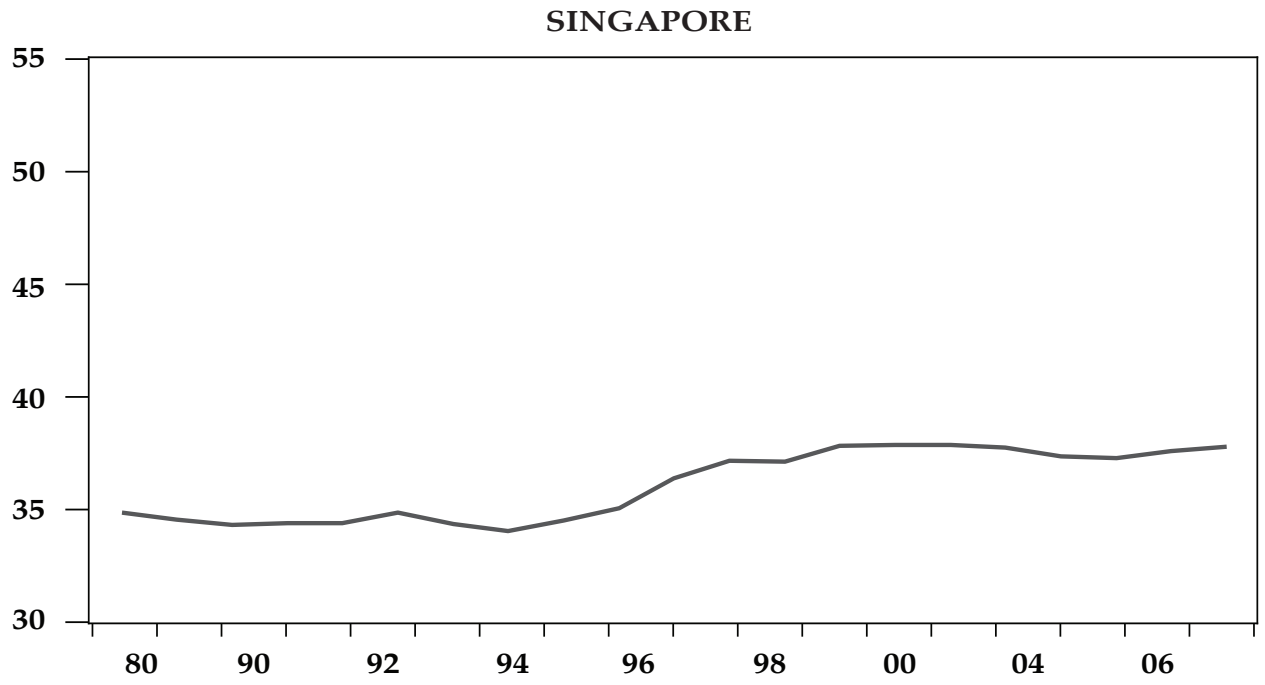

Figure 2. Income Inequality in Eight Asian Countries (Continued)

As a preliminary look at whether the financial market size is related to income inequality, we pool the data from the eight countries and plot them in Figure 3. In the figure, we also plot the relation between income inequality and credit to the private sector for comparison. From the figure, we note the U-shaped relation between the financial sector size and income inequality. Meanwhile, the non-linear relation between credit and inequality is less apparent. These observations further serve as a motivation for formal modelling of the relation between financial market size and income inequality, which we turns to next.

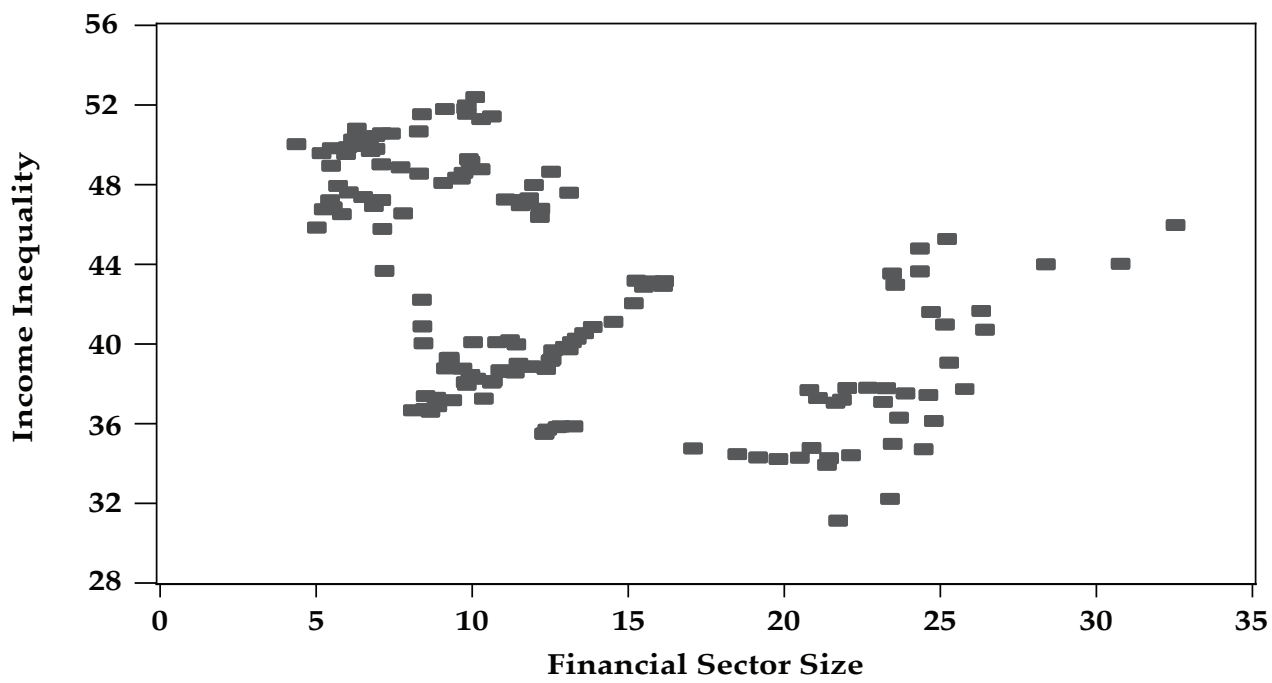

Figure 3. Inequality, Financial Sector Size and Financial Intermediation 


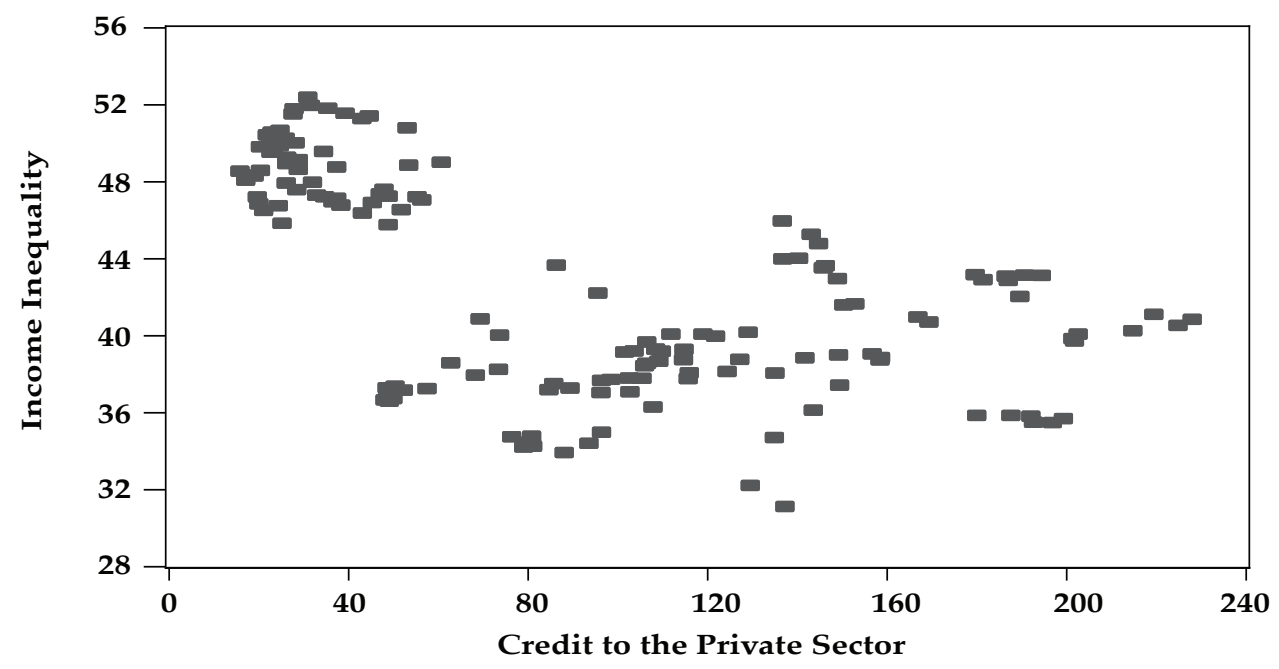

Figure 3. Inequality, Financial Sector Size and Financial Intermediation (Continued)

\section{METHODOLOGY}

In line with existing studies on finance - inequality relation, we specify income inequality to be a function of financial sector size and its other determinants as:

$$
\operatorname{gini}_{i t}=\beta_{1} \text { finsize }_{i t}+\beta_{2} \text { finsize }_{i t}^{2}+\theta X_{i t}+\mu_{i}+v_{i t}
$$

where gini $_{i t}$ is the natural log of GINI coefficient, finsize ${ }_{i t}$ is the natural log of a financial sector size, $X_{i t}$ is a vector of controlled variables, $\mu_{i}$ is the country-specific effects, $v_{i t}$ is the disturbance term, and the subscripts $i$ and $t$ index country and year. In (1), we include finsize and squared finsize to capture potential non-linear relations between income inequality and financial sector size. While the financial markets may be amicable to equal income distribution, we posit that the oversized financial markets can be harmful. Accordingly, it is expected that $\beta_{1}<0$ and $\beta_{2}>0$. These are the key parameters of the model to be estimated.

As for the controlled variables, we consider economic growth, inflation, trade openness, banking and stock market development indicators, government size, and infrastructure. We use real GDP growth instead of a normally-used level real GDP since the latter is potentially highly correlated with other determinants of inequality such as financial market size and inflation (Ang, 2010; Jalil 2012). To the extent that economic growth helps alleviate income inequality, we expect real GDP growth to enter negatively in the GINI equation. Inflation is another main variable normally included in the inequality studies. However, its impact on income inequality can be either positive or negative. On one hand, increasing inflation results in reduction in real wages and thus in unemployment. This will help equalize income distribution. On the other hand, inflation may hurt the poor more than the rich since it involves arbitrary redistribution of income. Moreover, 
facing macroeconomic uncertainty, the rich may be in a better position to hedge against any risk as compared to the poor. Thus, inflation can worsen income distribution. Likewise, the relation between trade openness and income inequality cannot be a priori signed. To the extent that trade narrows the wage gap between skilled and unskilled labour, as posited by standard trade theory, trade can bring positive benefit to a country's income distribution (Asteriou et al., 2014). Still, its impact on inequality is not unconditional and depends on various factors such as whether the country is labour abundant or capital abundant (Papanek and Kyn (1986), the country's level of development (Hamori and Hashiguchi, 2012), and the comparative returns to education and skills (Stiglitz, 1988).

Financial development, represented normally by total credit to private sector, bank credit to private sector, M2 and stock market capitalization (all as ratios of GDP), and its role in income distribution has been much debated in the literature as noted earlier. The size of the financial sector may reflect increasing financial development. Hence, all these measures are included to control for the level of financial development along a similar line as Beck et al. (2014). We expect financial development to carry a negative coefficient. The impact of government size on income inequality can be favourable unless government expenditure reflects disproportionately the interest of the rich. Finally, infrastructure is viewed to have equalizing effect on income distribution. All variables except the GDP growth rate and inflation rate are expressed in natural logarithm.

Our baseline specification takes economic growth, inflation, and trade as controlled variables and is estimated using the panel fixed-effect estimator. In opting for the fixed effect model, validation is made that the individual-specific effect is present using the Breusch and Pagan lagrangian multiplier test and that there is correlation between the model's error term and explanatory variables using the Hausman test statistics. For the latter case, the fixed effect model is consistent regardless of whether the error term and the explanatory variables are correlated. Meanwhile, the random effect model is consistent and efficient only when the null of no correlation is not rejected.

Departing from the baseline results, we perform several robustness checks. These include the extensions of the baseline specification and exclusion of a country at a time from the sample. The details of these robustness checks are provided in the next section.

\section{ESTIMATION RESULTS}

In this section, we first discuss the basic results. Then, we perform further analyses to ascertain whether the implications of the financial sector size on income inequality remains robust to alternative model specifications and to sample countries.

\subsection{Baseline Results}

Table 2 presents baseline estimation results. In the table, we provide the results from pooled OLS, random-effect panel, and fixed-effect panel estimators as well as corresponding statistics for the estimation choice. The Breusch-Pagan LM test for the homogeneity of country-specific effect presented at the bottom of the 
Table soundly rejects the homogeneity assumption of the pooled OLS regression. In addition, the Hausman test also rejects the absence of correlation between the included explanatory variables and the error term. While we may observe consistent results across the three estimators, the fixed-effect panel estimator seems to be most appropriate.

Table 2.

Baseline Results

\begin{tabular}{llll}
\hline \multicolumn{1}{c}{ Finance Size: Share of Value Added } \\
\hline \multicolumn{1}{c}{ Variables } & \multicolumn{1}{c}{ Pooled } & \multicolumn{1}{c}{ Random } & \multicolumn{1}{c}{ Fixed } \\
\hline Constant & $5.0354^{* * *}$ & $4.3769^{* * *}$ & $4.3740^{* * *}$ \\
FinSize & $-0.8198^{* * *}$ & $-0.7675^{* * *}$ & $-0.8832^{* * *}$ \\
FinSize2 & $0.1395^{* * *}$ & $0.1601^{* * *}$ & $0.1859^{* * *}$ \\
GDP Growth & $-0.0054^{* *}$ & $-0.0029^{* *}$ & $-0.0027^{* *}$ \\
Inflation & 0.0003 & $-0.0022^{* * *}$ & $-0.0022^{* * *}$ \\
Trade & $-0.0298^{* *}$ & $0.0607^{* *}$ & $0.0890^{* * *}$ \\
& & & \\
BP LM Tesys & $474.85^{* *}$ & & -- \\
Hausman & -- & & $47.41^{* * *}$ \\
Obs. & 156 & 156 & 156 \\
\hline
\end{tabular}

Note: ${ }^{*}{ }^{* *}$, and ${ }^{* * *}$ indicate significance at $10 \%, 5 \%$ and $1 \%$ respectively.

The results we obtained for the controlled variables using the fixed-effect estimator are in close resemblance to those by Ang (2010) for the case of India. Namely, the GDP growth and inflation rate are negatively and significantly related to the GINI coefficient while trade openness is positively related to GINI. Jalil (2012) also documents the negative relation between economic growth and inequality in China. Perera and Lee (2013), however, find no significant relation between the two in their analysis of selected Asian countries. The inequality effect of trade openness is also documented by Agnello et al. (2012), although Mookerjee and Kalipioni (2010) indicate income-equalizing effect of trade openness. As for the inflation rate, inflation is found to increase income inequality by Mookerjee and Kalipioni (2010) and to be insignificant by Law et al. (2014). These differences may be due to different sample countries and estimation procedures. In the context of the eight Asian countries under study, economic growth, and inflation seems to be beneficial to income distribution while trade can be harmful.

Turning to our main theme, we find evidence supporting the U-shaped relation between the financial sector size and income inequality as reflected by the negative coefficient of finance sector size and the positive coefficient of squared financial sector size. Based on the fixed effect estimates, the threshold size of the financial sector beyond which the sector has a negative bearing on income distribution is 
$11 \%$ of the total value added ${ }^{6}$. All our sample countries except India and South Korea have surpassed the $11 \%$ threshold point. Accordingly, in these countries, the expansion of the financial sector size may have negative repercussion on income distribution. In other words, the widening income inequality experienced by majority of this group of countries may be in part due to the expanding financial sector size.

\subsection{Robustness}

In order to add credence to our basic results, we perform robustness along (i) extension of the baseline specification and (ii) exclusion of a country at a time.

The first robustness check involves adding to the baseline specification sets of additional controlled variables. More specifically, the sets of additional controlled variables are formed from the followings: measures of financial development, government size, and infrastructure. Table 3 provides the fixed-effect estimation results with these additional controlled variables. Regressions (1) to (4) add alternatively the following financial development indicators - total credit to private sector, bank credit to private sector, M2, and stock market capitalization (all as ratios of GDP). Regressions (5) and (6) add respectively government size and infrastructure. In regressions (7) to (10), we add altogether government size, inflation, and an indicator of financial development.

Table 3.

Fixed-Effect Estimation Results with Additional Controlled Variables

\begin{tabular}{|c|c|c|c|c|c|c|c|c|c|c|}
\hline Variables & (1) & (2) & (3) & (4) & (5) & (6) & (7) & (8) & (9) & (10) \\
\hline Constant & $4.3815^{* * *}$ & $4.3545^{* * *}$ & $4.3286^{* * *}$ & $4.3844^{* * *}$ & $3.8655^{* * * *}$ & $4.1200^{* * *}$ & $3.5204^{* * *}$ & $3.5797^{* * *}$ & $3.7363^{* * *}$ & $3.7746^{* * *}$ \\
\hline FinSize & $-0.9024^{* * *}$ & $-0.8366^{* * *}$ & $-0.8942^{* * *}$ & $-0.8900^{* * *}$ & $-0.7798 * * *$ & $-0.7986^{* * *}$ & $-0.5032^{* * *}$ & $-0.5315^{* * *}$ & $-0.7328^{* * *}$ & $-0.7661^{* * *}$ \\
\hline FinSize2 & $0.1889^{* * *}$ & $0.1782^{* * *}$ & $0.1873^{* * *}$ & $0.1872 * * *$ & $0.1723^{* * *}$ & $0.1675^{* * *}$ & $0.1259^{* * *}$ & $0.1282^{* * *}$ & $0.1600^{* * *}$ & $0.1669^{* * *}$ \\
\hline Growth & $-0.0062^{* *}$ & $-0.0027^{* *}$ & -0.002 & $-0.0027^{* *}$ & -0.0016 & $-0.0033^{* * *}$ & $-0.0023^{* *}$ & $-0.0023^{* *}$ & $-0.0021^{*}$ & $-0.0025^{* *}$ \\
\hline Inflation & $-0.0022^{* * *}$ & $-0.0022^{* * *}$ & $-0.0182^{2 *}$ & $-0.0022^{* * *}$ & -0.0003 & $-0.0027^{* * *}$ & -0.0004 & -0.0005 & -0.0008 & -0.0009 \\
\hline Trade & $0.0887^{* * *}$ & $0.0886^{* * *}$ & $0.0610^{* *}$ & $0.0871^{* * *}$ & $0.0616^{* * *}$ & $0.1467^{* * *}$ & $0.1060^{* * *}$ & $0.0985^{* * *}$ & $0.1020^{* * *}$ & $0.1013^{* * *}$ \\
\hline Credit & 0.0053 & - & -- & - & -- & - & $-0.0546^{* *}$ & -- & -- & -- \\
\hline Bank Credit & - & -0.0105 & -- & - & - & -- & -- & $-0.0414^{* * *}$ & -- & -- \\
\hline M2 & - & -- & $0.0412^{* *}$ & - & -- & -- & -- & -- & 0.0054 & -- \\
\hline Market Cap & -- & -- & -- & 0.0015 & -- & -- & -- & -- & -- & $0.0111^{*}$ \\
\hline Gov & - & -- & - & - & $0.1871^{* * * *}$ & - & $0.2135^{* * *}$ & $0.1987^{* * *}$ & $0.1661^{* * *}$ & $0.1680^{* * *}$ \\
\hline Infra & - & - & -- & - & -- & $-0.0360^{* * *}$ & $-0.0279^{* * *}$ & $-0.0251^{* * *}$ & $-0.0255^{* * *}$ & $-0.0316^{* * *}$ \\
\hline Obs. & 156 & 156 & 156 & 156 & 156 & 156 & 156 & 156 & 156 & 156 \\
\hline
\end{tabular}

Note: ${ }^{*}{ }^{* *}$, and ${ }^{* * *}$ indicate significance at $10 \%, 5 \%$ and $1 \%$ respectively.

6 This is computed based on differentiating (1) with respect to the financial sector size and setting it equal to zero to get the threshold financial sector size. That is, $\frac{d \text { gini }}{\text { dfinsize }}=\beta_{1}+2 \beta_{2}$ finsize $=0$. 
Among the newly added controlled variables, we document some evidence supporting the significant role of financial development to income distribution and robust evidence on the relation between government size and infrastructure on one hand and income inequality on the other hand. While the government size seems to be detrimental to income distribution, infrastructure development tends to equalize income distribution in these countries. With only one exception, our baseline results remain robust to the extension of the baseline model. The exception is the coefficient of inflation turns insignificant when the government size, infrastructure and a financial development measure are added into the regressions (i.e. regressions (7) to (10)). Central to our present thesis, the U-shaped relation between financial sector size and income inequality is further substantiated.

In the second robustness check, we exclude one country at a time from the full sample in the spirit of the Jackknife regression used by Dearmon and Grier (2009). To be extensive, we re-estimate the baseline regression as given in Table 2 and the 10 extended regressions in Table 3, yielding a total of 11 regressions for each country exclusion or a total of 88 regressions overall. Table 4 summarizes the results from this exercise, i.e. the average estimated coefficients and the number of significance out of the total regressions that a concerned explanatory variable entering the regressions. Among the controlled variables, the significance of government size and infrastructure is largely robust across regressions. Similar to the results from Table 3, increasing government size tends to worsen income distribution while infrastructure development improves it. The significance of international trade also appears to be robust. A closer look at the results, however, reveal an interesting finding. Namely, the coefficient of international trade, which is positively signed in most regressions, turns negative and significant when Singapore is excluded from the sample. Thus, it seems that Singapore drives the positive correlation between trade and income inequality in these countries. As for the remaining variables, the results are less robust. Economic growth appears significant in majority of regressions; but, its significance drops substantially when Indonesia or Japan is excluded from the sample. The significance of inflation also drops to only one regression out of 11 regressions when Hong Kong or Singapore is excluded. Finally, the significance of financial development indicators also tends to depend on which indicator is used. 
Table 4.

Average Coefficient Estimates - Country Exclusion

\begin{tabular}{|c|c|c|c|c|c|c|c|c|c|c|c|}
\hline \multirow{2}{*}{$\begin{array}{l}\text { Country } \\
\text { Excluded }\end{array}$} & \multicolumn{11}{|c|}{ Variables } \\
\hline & Finsize & Finsize2 & Growth & Inflation & Trade & Credit & B Credit & M2 & Mkt Cap & Gov & Infra \\
\hline HK & -0.5083 & 0.1149 & -0.0018 & -0.0002 & 0.0647 & -0.0224 & -0.0305 & 0.0088 & -0.0032 & 0.1481 & -0.0229 \\
\hline \# significance & $10 / 11$ & 11-Nov & 6/11 & $1 / 11$ & 10/11 & $1 / 2$ & $1 / 2$ & $0 / 2$ & $0 / 2$ & $5 / 5$ & $5 / 5$ \\
\hline IN & -0.8587 & 0.1831 & -0.0026 & -0.0014 & 0.0882 & -0.0217 & -0.0245 & 0.0299 & 0.0101 & 0.1925 & -0.0358 \\
\hline \# significance & $11 / 11$ & 11-Nov & 9/11 & 6/11 & 9/11 & $1 / 2$ & $1 / 2$ & $1 / 2$ & $1 / 2$ & $5 / 5$ & $5 / 5$ \\
\hline IND & -1.0745 & 0.2184 & -0.0015 & -0.007 & 0.1097 & -0.0664 & -0.057 & -0.0144 & 0.0002 & 0.1794 & -0.0406 \\
\hline \# significance & $11 / 11$ & 11-Nov & 2/11 & 11-Nov & 11-Nov & $2 / 2$ & $2 / 2$ & $1 / 2$ & $0 / 2$ & $5 / 5$ & $3 / 5$ \\
\hline $\mathrm{JP}$ & -0.7245 & 0.1516 & -0.0019 & -0.0014 & 0.0924 & -0.0173 & -0.0146 & 0.039 & 0.0115 & 0.1554 & -0.0315 \\
\hline \# significance & $11 / 11$ & 11-Nov & 3/11 & 6/11 & 11-Oct & $1 / 2$ & $1 / 2$ & $1 / 2$ & $1 / 2$ & $5 / 5$ & $5 / 5$ \\
\hline KR & -0.7513 & 0.1617 & -0.0028 & -0.0015 & 0.0945 & -0.0258 & -0.028 & 0.087 & 0.0076 & 0.2282 & -0.0316 \\
\hline \# significance & $11 / 11$ & 11-Nov & 9/11 & 6/11 & $11-0 \mathrm{ct}$ & $1 / 2$ & $1 / 2$ & $2 / 2$ & $1 / 2$ & $5 / 5$ & $5 / 5$ \\
\hline MY & -0.7008 & 0.1618 & -0.003 & -0.0015 & 0.0928 & -0.0292 & -0.0276 & 0.017 & 0.0063 & 0.1691 & -0.0296 \\
\hline \# significance & $11 / 11$ & 11-Nov & $11-0 c t$ & 6/11 & 11-Nov & $1 / 2$ & $1 / 2$ & $0 / 2$ & $1 / 2$ & $5 / 5$ & $5 / 5$ \\
\hline $\mathrm{PH}$ & -0.8105 & 0.1768 & -0.002 & -0.0012 & 0.1074 & 0.0006 & -0.0075 & 0.0237 & 0.0034 & 0.2414 & -0.0187 \\
\hline \# significance & $11 / 11$ & 11-Nov & $5 / 11$ & 6/11 & 11-Nov & $0 / 2$ & $0 / 2$ & $1 / 2$ & $0 / 2$ & $5 / 5$ & $3 / 5$ \\
\hline SG & -0.5859 & 0.12 & -0.005 & -0.0009 & -0.0167 & -0.0934 & -0.0992 & -0.0455 & 0.0005 & 0.0592 & -0.0686 \\
\hline \# significance & $11 / 11$ & 11-Nov & 9/11 & 1/11 & $5 / 11$ & $2 / 2$ & $2 / 2$ & $1 / 2$ & $1 / 2$ & $5 / 5$ & $5 / 5$ \\
\hline
\end{tabular}

Note: $\mathrm{HK}=$ Hong Kong; IN = India; IND = Indonesia; JP = Japan; KR = South Korea; MY = Malaysia; $\mathrm{PH}=$ The Philippines; SG = Singapore

The results are overwhelmingly robust in suggesting a non-linear relation between the financial sector size and income inequality, regardless of which country is excluded from the sample. In line with the baseline result, the threshold financial sector size computed for each case ranges from a minimum of 8.65 (Malaysia excluded) to 11.87 (Singapore excluded) and has the overall average of 10.28. As noted, majority of these countries have their financial sector sizes to surpass $10 \%$ of the total valued added. Accordingly, potential adverse bearings on income distribution from further expansion of the sector needs policy attention.

\section{CONCLUSION}

The paper draws a panel sample of eight fast-growing Asian countries to assess the income inequality effect of the financial sector size. From the estimation, we uncover a U-shaped relation between financial sector size as measured by the share of financial sector value added in the total value added and the GINI coefficient. This result is robust to the extension of our basic model to include other potential determinants of income inequality including financial development indicators and to exclusion of a country at a time from the panel sample. This means that the impact of financial sector size on income distribution is independent of its 
financial intermediation activities and is not driven by any country in the sample. Our estimates suggest that the size of the financial sector has favourable bearing on income equality if it is not larger than $10 \%-11 \%$ of the total value added. Once the sector assumes more than $11 \%$ of the total value added, it tends to widen income distribution. Apart from this main theme, we also note the positive contribution of economic growth and infrastructure development to income equality and income inequality implications of international trade and government expenditures.

Our results echo well the recent concern over the negative macroeconomic implications of oversized financial sector and add well to the recent results emphasizing the growth-impeding effects of oversized financial sector. More precisely, fast-growing financial sector size may have not added to resolving observed widening income distribution as many might expect. Instead, it can make the problem worse once it surpasses beyond a certain size threshold. Our findings should serve as a caution to policymakers in the sample countries in particular and in other countries in general in designing finance-led growth policies. Still, to be more concrete, we suggest further extension of the study particularly to other groups of countries at different level of developments such that more robust inferences can be drawn.

\section{REFERENCES}

Abdmoulah, W., Jelili, R.B., 2013. Access to finance thresholds and the financegrowth nexus. Economic Papers, 32(4), 522-534.

Agnello, L., Mallick, S.K., Sousa, R.M., 2012. Financial reforms and income inequality. Economics Letters 116, 583-587.

Ang, J.B., 2010. Finance and inequality: the case of India. Southern Economic Journal, 76, 738-761.

Asteriou, D., Dimelis, S., Moudatsou, A., 2014. Globalization and income inequality: a panel data econometric approach for the EU27 countries. Economic Modelling, 36, 592-599.

Bahmani-Oskooee, M., Zhang, R. (2015). On the impact of financial development on income distribution: time series evidence. Applied Economics, 47(12), 12481271.

Banerjee, A., Newman, A. (1993). Occupational choice and the process of development. Journal of Political Economy, 101, 274-298.

Beck, T., Degryse, H., Kneer, C. (2014). Is more finance better? Disentangling intermediation and size effects of financial systems. Journal of Financial Stability, 10, 50-64.

Beck, T., Demirguc-Kunt, A., Levine, R. (2007). Finance, inequality and the poor. Journal of Economic Growth, 12, 27-49.

Checchetti, G., Kharroubi, E. (2012). Reassessing the impact of finance on growth. BIS Working Paper No. 381, Bank for International Settlement.

Clarke, G., Xu, L., Zou, H. (2006). Finance and income inequality: what do the data tell us? Southern Economic Journal, 72(3), 578-596.

Classens, S., Perotti, E. (2007). Finance and inequality: channels and evidence. Journal of Comparative Economics, 35(4), 748-773. 
Cœurè, B. (2014). On the optimal size of the financial sector. Speech at the ECB Conference: The Optimal Size of the Financial Sector. Frankfurt, 2 September, 2014. https:// www.ecb.europa.eu/press/key/date/2014/html/sp140902.en.html(accessed: June 10, 2015).

Creel, J., Hubert, P., Labondance, F. (2015). Financial stability and economic performance. Economic Modelling, 48, 25-40.

Dearmon, J., Grier, K. (2009). Trust and development. Journal of Economic Behavior E Organization, 71, 210-220.

Demetriades, P., Law, S.H. (2006). Finance, institutions and economic development. International Journal of Finance and Economics, 11, 245-260.

Galbraith, J.K., Kum, H. (2005). Estimating the inequality of household income: A statistical approach to the creation of a dense and consistent global data set. Review of Income and Wealth, 51(1), 115-143.

Galor, O., Zeira, J. (1993). Income distribution and macroeconomics. Review of Economics Studies, 60, 35-52.

Gimet, C., Lagoarde-Segot, T. (2011). A close look at financial development and income distribution. Journal of Banking and Finance, 35, 1698-1713.

Greenwood, J., Jovanovic, B. (1990). Financial development, growth and the distribution of income. Journal of Political Economy, 98, 1076-1107.

Hamori, S., Hashiguchi, Y. (2012). The effect of financial deepening on inequality: Some international evidence. Journal of Asian Economics, 23, 353-359.

Herzer, D., Nunnenkamp, P. (2012). The effect of foreign aid on income inequality: evidence from panel cointegration. Structural Change and Economic Dynamics, 23(3), 245-255.

Huang, H.-C., Lin, S.-C. (2009). Non-linear finance-growth nexus: a threshold with instrumental variable approach. Economics of Transition, 17(3), 439-466.

Jalil, A. (2012). Modeling income inequality and openness in the framework of Kuznets curve: new evidence from China. Economic Modelling, 29, 309-315.

Kaufmann, D., Kraay, A., Mastruzzi, M. (2008). Governance matters VII: aggregate and individual governance indicators, 1996-2007. Policy Research Working Paper no. 4654, World Bank, Washington D.C.

Kim, D.-H., Lin, S.-C. (2011). Nonlinearity in the financial development-income inequality nexus. Journal of Comparative Economics, 39, 310-325.

Law, S.H., Azman-Saini, W.N.W., Ibrahim, M.H. (2013). Institutional quality thresholds and finance-growth nexus. Journal of Banking and Finance, 37, 53735381.

Law, S.H., Singh, N. (2014). Does too much finance harm economic growth?. Journal of Banking and Finance, 41, 36-44.

Law, S.H., Tan, H.B., Azman-Saini, W.N.W. (2014). Financial development and income inequality at different levels of institutional quality. Emerging Markets Finance and Trade, 50, 21-33.

Mokerjee, R., Kalipioni, P. (2010). Availability of financial services and income inequality: The evidence from many countries. Emerging Markets Review, 11, 404-408.

Mookherjee, D., Ray, D. (2003). Persistent inequality. Review of Economic Studies, 70, 369-312. 
Papanek, G.F., Kyn, O. (1986). The effect on income distribution of development, the growth rate and economic strategy. Journal of Development Economics, 23(1), 55-65.

Perera, L.D.H., Lee, G.H.Y. (2013). Have economic growth and institutional quality contributed to poverty and inequality reduction in Asia?. Journal of Asian Economics, 27, 71-86.

Rajan, R., Zingales, L. (2003). The great reversals: the politics of financial development in the twentieth century. Journal of Financial Economics, 69, 5-50.

Rodriguez-Pose, A., Tselios, V. (2009). Education and income inequality in the regions of the European Union. Journal of Regional Science, 49, 411-437.

Stiglitz, J. (1988). More instruments and broader goals: moving toward the postWashington consensus. WIDER Annual Lecture 2. UNU-WIDER, Helsinki.

Timmer, M.P., de Vries, G. J., de Vries, K. (2014). Patterns of structural change in developing countries. GGDC Research Memorandum 149.

University of Texas Inequality Project. (2008). Estimated household income inequality data set 2008. Retrieved from http://utip.gov.utexas.edu/data.html

Yilmazkuday, H. (2011). Thresholds in the finance-growth nexus: a cross-country analysis. The World Bank Economic Review, 25(2), 278-295. 
This page is intentionally left blank 